\title{
THE IMPLEMENTATION OF INTERNATIONAL AGREEMENTS IN THE POLISH LEGAL SYSTEM. THE SELECTED ASPECTS OF PRACTICE IN RECENT TWO DECADES
}

\begin{abstract}
The issue of the implementation of international agreements in the domestic legal system is of substantial significance. It guarantees the efficiency of international law in the domestic space. The article presents the selected aspects of this process in reference to the practice of the Republic of Poland, within the last two decades with the particular consideration of the position of the Council of Ministers in this respect. The subject of analysis is the legal character (and its sources) of the obligation of the implementation of treaties, both at the level of international and domestic law. Subsequently, the conditions of the implementation have been considered, including the costs and the issue of application of international agreements. The consequences of non-implementation of a treaty for enforceability of its provisions within the Polish legal system constitute the subject of the analysis in the last section of the paper.
\end{abstract}

Assistant Professor, Department of International and European Law, Cardinal Stefan Wyszyński University in Warsaw, ORCID: 0000-0003-0784-8293. The article represents exclusively the private views of the author. The author would like to thank Michał Kobyliński and anonymous reviewer for their helpful remarks. All the mistakes are the sole responsibility of the author. 
Keywords: implementation of international agreements, self-executing norms, Constitution and international law, transformation of international agreements, pacta sunt servanda

\section{Introduction}

The issue of the implementation of international agreements in the domestic legal system is of substantial significance. It guarantees the efficiency of the international law in the internal space. The aim of the article is to present the selected aspects of this process in reference to the practice of the Republic of Poland, within the last two decades with the particular consideration of the position of the Council of Ministers in this respect. Therefore, the article predominantly focuses on the Polish practice, and consequently, it does not contain an analysis of the monism and dualism theories, and their significance in the Polish legal system. ${ }^{1}$

The article's structure is as follows. First, the legal character (and its sources) of the obligation of the implementation of treaties both, at the level of the international law, and of the domestic law, has been presented. Then, the conditions of the implementation have been considered, including the costs and the issue of application of international agreements. The consequences of not implementing a treaty for enforceability of its provisions within the Polish legal system, constitute the subject of the analysis in the last section of the paper.

Due to the extensiveness of the subject matter, the article does not discuss the issue of the implementation of the Convention for the Protection of Human Rights and Fundamental Freedoms and the judgements of the European Court of Human Rights, issued thereunder, into the Polish legal

1 As a side note, it may only be underlined that the passage from the judgement of the Constitutional Tribunal regarding the EU Law "The very conception and the model of European law, have created a new situation, where there are two autonomous legal systems simultaneously in effect. Their mutual interrelation cannot be described comprehensively by the traditional theories of monism and dualism, in the alignment: domestic law - international law' (Judgement of 11.5.2005, File no. K 18/04, para. 6.3), to a large extent also refers to the significance of the international law in local systems. Cf. 'although the practice is not uniform, the Polish system of implementing international agreements into the domestic law is closer to monist rather than dualist system', A. Wyrozumska, Umowy międzynarodowe. Teoria i praktyka (International Agreements. Theory and Practice), Warsaw 2006, p. 599. 
system. ${ }^{2}$ Due to the same reasons, the issue of the implementation of the EU law and of the treaties on the protection of human rights adopted at the UN forum binding Poland, as well as, of the international humanitarian law are not covered by this analysis. ${ }^{3}$ Lastly, the article is not dedicated to the evaluation of the implementation of treaty obligations by Poland, as implemented by relevant treaty bodies. ${ }^{4}$

\section{The obligation of implementation of treaties from the perspective of the international law}

According to the international law, a state bound with international agreements undertakes to adjust its own domestic law to its international legal obligations. This requirement may be deduced from the pacta sunt servanda principle and its associated principle of fulfilling obligations in good faith (Article 2(2) of the Charter of the United Nations ${ }^{5}$ and Article 26 of the Vienna Convention on the Law of Treaties - VCLT), as well as, the principle of not invoking the provisions of domestic law as justification for

2 In this scope, one should pay attention to the exceptional role of the interministerial group for the European Court of Human Rights, established by the Prime Minister in 2007, and led by the Ministry of Foreign Affairs of the Republic of Poland. The Group monitors the execution of the judgements and decisions of the Court by the members of the Council of Ministers, and may formulate proposals of appropriate actions. The ministers relevant for the subject matter of the violation of the Convention, as stated by the Court, are obliged to translate and promulgate the judgement of the Court, and to prepare a plan of action and a report of its execution as scheduled in the ruling. In this context, one should also note that the Ministry of Foreign Affairs releases annual reports on the execution of the European Court of Human Rights' judgements by Poland, which are available at: https://bit.ly/priel2020-1-1.

3 The subject matter is relatively comprehensively discussed in the subsequent reports written by the Ministry of Foreign Affairs, on the implementation and the dissemination of the international humanitarian law. The last, $4^{\text {th }}$ report on this subject was published in 2019.

4 Regarding this procedure see: G. Ulfstein, T. Marauhn, A. Zimmermann (ed.), Making Treaties Work - Human Rights, Environment and Arms Control, CUP, Cambridge 2007.

'All Members... shall fulfil in good faith the obligations assumed by them in accordance with the present Charter'; M. Villiger, Commentary to Vienna Convention on the Law of the Treaties, Brill 2009 p. 363 and 367. 
the failure to perform a treaty rule (Article 27 of the VCLT). ${ }^{6}$ Additionally, both of the aforementioned provisions, therefore also the obligation of implementation, ${ }^{7}$ have a customary nature. ${ }^{8}$

Simultaneously, the implementation requirement is, at times, defined directly in some international agreements. ${ }^{9}$ This particularly applies to the founding treaties of regional integration organisations. ${ }^{10}$ An example of such a generally formulated obligation is Article 4(3) of the Treaty on European Union which includes the following: 'The Member States shall take any appropriate measures, general or particular, to ensure fulfilment of the obligations arising out of the Treaties or resulting from the acts of the institutions of the Union.' Additionally, some treaties adopted at the Council of Europe, ${ }^{11}$ the United Nations, ${ }^{12}$ or the International Labour

6 K. Schmalenbach, Article 27 Internal law and observance of treaties [in:] O. Dorr, K. Schmalenbach (eds.), 'The Vienna Convention on the Law of Treaties', Springer-Verlag Berlin Heidelberg 2012 p. 462; S.E. Nahlik, Kodeks prawa traktatów (Code of Law of Treaties), Państwowe Wydawnictwo Naukowe, Warsaw 1976, p. 185-186.

7 The Permanent Court of International Justice in advisory opinion of 21.2.1925 on the exchange of Greek and Turkish Populations, PCIJ, series B10, p. 20, stated as follows: '(...) a State which has contracted valid international obligations is bound to make in its legislation such modifications as may be necessary to ensure the fulfilment of the obligations undertaken.; P.-M. Dupuy, International Law and Domestic (Municipal) Law, [in:] 'Max Planck Encyclopaedia of Public International Law' (online edition), para. 43.

8 Certain German interests in Upper Silesia, PCJIL, Judgment of 26.5.1926, Series A7, p. 17, 22 and 42, as well as, Rights of the citizens of the United States in Morocco, Judgments of 27.8.1952, ICJ Rep. 1952, p. 176.

9 C. Mik, Polskie prawo stosunków międzynarodowych. Rozważania koncepcyjne (The Polish Law of International Relations. Conceptual Deliberations), [in:] C. Mik, Ł. Kułaga (ed.), 'Polskie prawo stosunków międzynarodowych' (The Polish Law of International Relations), TNOiK, Toruń 2018, p. 39.

10 C. Mik, Fenomenologia regionalnej integracji państw. Studium prawa międzynarodowego (Phenomenology of the Regional Integration of States. International Law Study), vol. II, Regionalne organizacje integracyjne z perspektywy analitycznej prawa międzynarodowego (Regional Integration Organisations from the Analytical Point of View of the International Law), Beck, Warsaw 2019, p. 588-596.

11 See for example: the Convention for the Protection of Individuals with regard to Automatic Processing of Personal Data (Article 4(1)); the Convention for the Protection of Human Rights and Dignity of the Human Being with regard to the Application of Biology and Medicine: the Convention on Human Rights and Biomedicine (Article 1); the Council of Europe Convention on preventing and combating violence against women and domestic violence (Article 4).

12 See for example: the International Covenant on Civil and Political Rights (Article 2(2)); the Convention on the Elimination of All Forms of Discrimination against Women 
Organisation, ${ }^{13}$ include resolutions that clearly define the implementation requirement.

In principle, the international law leaves the choice of the means of implementation of an international standard into the domestic system to the domestic legislator. ${ }^{14}$ It is coherent with the principles of nonintervention in internal affairs and the sovereignty of a state. ${ }^{15}$ However, exceptions to this rule can be also stated. For example, the Treaty on Stability, Coordination and Governance in the Economic and Monetary Union of 2011, stipulates in Article 3(2) that 'The rules set out in paragraph 1 (regarding the governance of the government and local budget), shall take effect in the national law of the Contracting Parties (...) through provisions of binding force and permanent character, preferably constitutional, or otherwise guaranteed to be fully respected and adhered to (...)'. Similarly, the Convention on the Elimination of All Forms of Discrimination against Women defines that: 'States Parties (...) undertake: (a) To embody the principle of the equality of men and women in their national constitutions or other appropriate legislation (...) to ensure, through law and other appropriate means, the practical realization of this principle' (Article 2).

\section{The implementation obligation from the perspective of Polish constitutional law}

The requirement of the implementation of international agreements in the Polish legal system is related to the fact that, as stated by the Supreme Administrative Court in the judgment of 29.12.1999, 'the binding force of the treaty on the grounds of the international law is insufficient for its

(Article 2); the Convention against Torture and Other Cruel, Inhuman or Degrading Treatment or Punishment (Article 2(1)); the United Nations Convention against Transnational Organized Crime (Article 5).

13 Violence and Harassment Convention, 2019 (Article 4); Maritime Labour Convention, 2006 (Article 1)

14 S. Rosenne, Developments in the Law of Treaties 1945-1986, CUP, Cambridge 1989, p. 62; R. Kwiecień, Miejsce umów międzynarodowych w porządku prawnym państwa polskiego (Place of International Agreements in the Polish Legal System), Wydawnictwo Sejmowe, Warsaw 2000, p. 49.

15 A. Edgar, R. Thwaites, Implementing Treaties in Domestic Law: Translation, Enforcement and Administrative Law, 'Melbourne Journal of International Law' 2018, vol. 19, no. 1, p. 25-50. 
application by the domestic court'. ${ }^{16}$ This thesis is based on Article 91(1) of the Constitution of the Republic of Poland, stating that:

'After promulgation thereof in the Journal of Laws of the Republic of Poland (Dziennik Ustaw), a ratified international agreement shall constitute part of the domestic legal order and shall be applied directly, unless its application depends on the enactment of a statute.'

Therefore, the Constitution of the Republic of Poland clearly provides for the situation of the necessity of issuing legislative acts in order to enact the treaty as being in force in the domestic legal system, when its direct application is impossible. The obligation is also supported by the principle of the democratic state ruled by law (Article 2 of the Constitution), and the principle of respecting international law (Article 9 of the Constitution).

Furthermore, the principle of reliable legislation and the principle of trust, deduced from Article 2 of the Constitution, impose on the legislator the obligation of the clear and precise definition of prescriptions and proscriptions regarding the citizens, which is impeded in the situation of discrepancy between the acts and the international agreement in force. According to the Constitutional Tribunal 'The principle of the citizen's trust in the state and its established law is based on legal certainty, therefore, an assortment of features ascribed to law that ensure the individual's legal security; allow the individual to decide on own actions on the basis of the comprehensive knowledge of the premises of the actions of public institutions and of the legal consequences that may follow the aforementioned actions. ${ }^{17}$

Referring to Article 9 of the Constitution of the Republic of Poland it is to be noted that in the judgment regarding the European arrest warrant (hereinafter EAW judgement), the Constitutional Tribunal underlined the validity of the interpretation of this provision as reflecting the international legal principle of pacta sunt servanda. ${ }^{18}$ In the same judgment, the Constitutional Tribunal did not exclude the necessity of introducing an amendment to the Constitution itself in order to adjust it to Polish international obligations. ${ }^{19}$

16 Judgment of the Supreme Administrative Court of 29.12.1999, I SA /Po 3057/98, ONSA 2001, no. 1, item 34, p. 331.

17 Judgment of 19.3.2007, K 47/05.

18 Judgment of 27.4.2005, File no. P 1/05, para. 5.3, see also para. 2.4.

19 Judgment of 27.4.2005, File no. P 1/05, para. 5. 


\section{The concept of implementation. The methods of implementation}

In EAW judgement, the Constitutional Tribunal indicated the obligation of state institutions to introduce 'appropriate changes in the domestic legal system' and 'taking particular action by the public authorities, in accordance with their given competences'. ${ }^{20}$ This allows for a distinction between formal and substantive implementation.

The concept of formal implementation encompass a variety of classic methods of introducing international legal norms into the domestic system. ${ }^{21}$ These include, among others, transformation, the validity of proprio vigore and referral. Despite the fact that these concepts, as accurately indicated by Jarosław Sozański, ${ }^{22}$ do not have a universally accepted definition, they are acknowledged and are of crucial value for systematization of the discussed subject matter.

The transformation means a transition of international law norms into domestic law norms. ${ }^{23}$ The examples of explicit transformations in Polish practice primarily include:

- The Act of 22.6.2001 on the execution of the Convention on the Prohibition of the Development, Production, Stockpiling and Use of Chemical Weapons; ${ }^{24}$ as well as;

- The Act of 9.10.2015 on the execution of the Agreement between the Government of the Republic of Poland and the Government of the United States of America to improve International Tax Compliance and to Implement FATCA. ${ }^{25}$

20 Judgment of 27.4.2005, File no. P 1/05, para. 5.5.

21 F.G. Jacobs, The effect of treaties in domestic law, [in:] F.G. Jacobs, S. Roberts (eds.), 'The Effect of Treaties in Domestic Law', Sweet and Maxwell, London 1987, p. XXIV.

22 J. Sozański, Implementacja umów międzynarodowych do systemów prawa krajowego, ze szczególnym uwzględnieniem Włoch (w tym status regionów) (Implementation of International Agreements into Domestic Legal Systems with a Particular Consideration of Italy (Including the Status of Regions), 'Roczniki Nauk Prawnych' 2007, vol. XVII, no. 2 , p. 38.

${ }^{23}$ K. Schmalenbach, Article 27 Internal law and observance of treaties, [in:] O. Dorr, K. Schmalenbach (eds.), 'The Vienna Convention on the Law of Treaties', Springer-Verlag Berlin Heidelberg 2012, p. 465; J. H. Jackson, Status of Treaties in Domestic Legal Systems: A Policy Analysis, 'AJIL' 1992, vol. 86, no. 2, p. 310-311.

24 Polish OJ 2001, item 812.

25 Polish OJ 2015, item 1712. 
A form of the transformation of international obligations, however, not resulting from an international agreement is an act of 15.12.2016 on the principles of the avoidance of double taxation and the prevention of evading taxation in terms of income tax as exercised by the Republic of Poland, and the territory, to which the tax law is applied, belonging to the competence of the Minister of Finance of Taiwan. ${ }^{26}$ As a justification of such a solution Council of Ministers stated: 'Taiwan is a geopolitical unit that de facto has a government, which effectively controls the territory and exercises ordinary government functions, including responsibility for international relations. As a de facto regime, it is a defective entity recognised by the international law with certain rights and obligations (...). The complex, international legal status of Taiwan caused the agreement to be concluded between two representatives equipped with particular competences, including the promotion of economic, trade and cultural relations between Taiwan and Poland. Therefore, the concluded agreement is not a classic international agreement. ${ }^{27}$

Additionally, the solution under Article 3(4) of the Aviation Law Act ${ }^{28}$ is also of exceptional nature, allowing the Minister of Transportation to implement the soft law norms (defined as 'international requirements') under a regulation. Considering the growing number and the significance of these norms, adoption of such methods of action seems to be entirely reasonable.

A referral is a solution assuming that the domestic law presents the institutions with the ability to apply the norms of the international law in particular situations. ${ }^{29}$ The examples of this method are the following regulations:

- Article 5(2a) of the Act concerning the Maritime Areas of the Republic of Poland ${ }^{30}$ explicitly refers to the necessity of 'considering the principles defined in the Convention' of the Law of the Sea.

26

27

28

29

Rzeczypospolitej Polskiej (Compliance with the International Law in the Light of the Constitution of the Republic of Poland), Zakamycze, Kraków 2003, p. 71.

30 Polish OJ 1991, item 131 with subsequent changes. 
- Article 3(1) of the Act of 3.7.2002 - the Aviation Law ${ }^{31}$ 'In terms of legal relations regarding civilian aviation, the Aviation Law provisions shall apply, unless the ratified international agreements that bind the Republic of Poland state otherwise.'

- Articles 3-5 of the Act of 19.8.2011 on a transportations of dangerous goods which refers to European Agreement of 30.9.1957 concerning the International Carriage of Dangerous Goods by Road as general framework, which should be taken into account when applying the Act. ${ }^{32}$

From the substantive perspective that the ratification of an international agreement, apart from the legislative execution of the agreement, also assumes the obligation of adjusting the legal practice (judicature, administrative decisions) to treaty requirements. In this context, the implementation shall mean ensuring full effectiveness of the agreement in a given state, i.e. taking all organisational (the organisation of administration, infrastructural issues) activities on all levels (the involvement of central and local authorities).

\subsection{Application of agreements and the issue of implementation}

According to Roman Kwiecien 'the application of international agreements in internal circumstances of the state, primarily refers to a situation, where an agreement independently, or in combination with a domestic legal act, provides the basis for a judgment or an administrative decision. ${ }^{33}$ Within this framework one may distinguish direct and indirect application. Indirect application of an international agreement, i.e. already mentioned transformation method, is the application of the acts of the domestic law

31 Similarly, Article 8(2) of the Act of 8.6.2001 on the Profession of Psychologist and the Vocational Self-government of Psychologists (Polish OJ 2001, item 763, with subsequent changes); Article 14(2) of the Act of 6.3.2018 on the Principles of Participation of Foreign Entrepreneurs and Other Foreign Persons in the Economic Activities in the Territory of the Republic of Poland (Polish OJ 2018, item 649, with subsequent changes).

32 Polish OJ 2011, item 1367.

33 R. Kwiecień, Miejsce..., p. 135; See also: K. Skubiszewski: Stosowanie i przestrzeganie prawa międzynarodowego $w$ państwie (Application and Compliance of the International Law in the State), 'Państwo i Prawo' 1984, no. 9, p. 18; T. Buergenthal, Self-executing and non-self-executing treaties in national and international law, 'RCADI' 1992, p. 368-392. 
adopted on the basis of an international agreement. ${ }^{34}$ Whereas, the direct application i.e. ex proprio vigore, is the 'ability to quote by individuals before state authorities in public-private or private-public relationships. The Court may base its own judgment directly on such an agreement. ${ }^{35}$ The condition for direct application is for the legal norm to be specific and comprehensive, so it may serve as the basis for deciding on the legal situation of legal entities. ${ }^{36}$ Thus, the provisions of the treaty has to be self-executing. ${ }^{37}$ In the case of the Bug River claims, the Constitutional Tribunal, in the context of the evaluation of the possibility of the direct application of the so-called Republican settlements, stated that 'the necessary (...) premise for the direct application of the agreement (...) is to define all normative elements in the very agreement that determine the use of a particular legal instrument. ${ }^{38}$ The Polish Supreme Court accepts even the possibility of direct application of criminal provisions, if they not only define the crime, but also determine the punishment. ${ }^{39}$ Therefore, such a norm should be clear, precise and comprehensive. ${ }^{40}$ With regard to the Convention on the Limitation Period in the International Sale of Goods, Supreme Court, after recognition that the Convention had met the above criteria, stated that it

34 R. Kwiecień, Miejsce..., p. 136.

35 A. Wyrozumska, Umowy międzynarodowe..., p. 573.

36 M. Czepelak, Umowa międzynarodowajakoźródto prawa prywatnego międzynarodowego (International Agreement as a Source of Private International Law), Wolters Kluwer, Warsaw 2008, p. 124.

37 D. Sloss, A treaty enforcement in domestic courts. A comparative analysis, [in:] D. Sloss (ed.) 'The Role of Domestic Courts in Treaty Enforcement: A Comparative Study', CUP, Cambridge 2009, p. 11-13.

${ }^{38}$ Judgment of the Constitutional Tribunal of 19.12.2002, K 33/02, para. 6.

39 Resolution of the Supreme Court of 17.3.2000 on the Convention of 1951 for the Supression of the Traffic in Persons and of the Exploitation of Prostitution of Others, I KZP 1/2000; for a different view see P. Hofmański, Recenzja: W. Czapliński, A. Wyrozumska, Sędzia krajowy wobec prawa międzynarodowego, Warszawa 2001 (Review: W. Czapliński, A. Wyrozumska, National Judge and the International Law), 'Państwo i Prawo' 2002, no. 5, p. 89-92.

40 A. Wyrozumska, Umowy międzynarodowe..., p. 573; R. Kwiecień, Miejsce..., p. 138. The author also indicates that the 'self-execution of the treaty is subject to the evaluation by the domestic law. Therefore, in practice, it is sometimes determined by the level of favourableness of a given legal system with regard to the international obligations. In states, where international agreements do not enjoy the institutional guarantee of effectiveness, the phenomenon of the self-execution of a treaty norm actually does not exist', p. 140. 
became: 'efficient proprio vigore without the need for separate implementation into the Polish law and it constitutes an integral part of this law. ${ }^{41}$

Similarly as in many states of the continental Europe, the Polish practice assumes that agreements regarding privileges and immunities are subject to direct application. Therefore, Poland did not adopt separate provisions that would introduce into the Polish legal system the privileges and the immunities of e.g. the European Organisation for Astronomical Research in the Southern Hemisphere, ${ }^{42}$ the European Organisation for the Exploitation of Meteorological Satellites ${ }^{43}$ or the European Space Agency. ${ }^{44}$ What is noteworthy, Poland also granted certain rights, under international agreements, to entities, which international legal status is not disputed, such as the Organisation for Security and Co-operation in Europe $^{45}$ and the European Border and Coast Guard Agency of the EU. ${ }^{46}$

41 Judgement of the Supreme Court of 25.6.2014, File no. IV CSK 611/13.

42 The agreement between the European Organisation for Astronomical Research in the Southern Hemisphere and the Government of the Republic of Poland regarding the terms and conditions of Poland's accession to the European Organisation for Astronomical Research in the Southern Hemisphere, signed on 28.10.2014, Polish OJ 2015, item 2172.

43 The Protocol on Privileges and Immunities of the European Organisation for the Exploitation of Meteorological Satellites (EUMETSAT), drawn up in Darmstadt on 1.12.1986, Polish OJ 2014, item 1042, 'The necessity to introduce changes in the Polish law with regard to the Protocol taking effect, is not considered' Sejm Paper no. 1883, 29.10.2013, p. 3.

44 The agreement between the Polish Government and the European Space Agency regarding Poland's accession to the Convention for the establishment of the European Space Agency and its terms and conditions, signed in Warsaw on 31.7.2012, Polish OJ 2013, item 61.

45 The agreement between the Government of the Republic of Poland and the Organisation for Security and Co-operation in Europe regarding the status of the Organisation of Security and Co-operation in Europe, in the Republic of Poland, signed in Warsaw on 28.6.2017, Polish OJ 2018, item 56; 'The entry into force of the Agreement shall not result in the necessity to introduce changes in the provisions of the domestic law', Sejm Paper no. 1872 of 25.9.2017, p. 7.

46 The agreement regarding the headquarters between the Republic of Poland and the European Border and Coast Guard Agency (Frontex), signed in Warsaw on 9.3.2017, Polish OJ 2017, item 1939; see also: M. Zieliński, Porozumienie dotyczqce siedziby agencji Unii Europejskiej Frontex w Polsce (aspekty konstytucyjne) (Agreement regarding the headquarters of the European Union Frontex Agency in Poland (Constitutional Aspects)), 'Przegląd Sejmowy' 2016, no. 1, p. 53-64; The author was an advocate of the finally adopted by the Council of Ministers solution of 'an agreement regarding the headquarters of the EU bodies (including Frontex) for the purpose of securing the privileges and the 
Simultaneously, the ability for direct application may be explicitly excluded by a treaty in order to protect the internal system. For example, Article 30.6(1) of the Comprehensive Economic and Trade Agreement (CETA) between Canada, of the one part, and the European Union and its Member States, of the other part, stipulates that it cannot be 'directly invoked in the domestic legal systems of the Parties. ${ }^{47}$

\section{Determinants of implementation}

\subsection{The scope of implementation}

In the light of jurisprudence of the Constitutional Tribunal, the requirement of implementation into the domestic system relates to all international agreements, not only those subject to ratification. Such an approach is in compliance with the international law. Particularly, Article 27 of the VCLT does not envisage precedence over the internal law solely to the treaties that require ratification. In the case of the Bug River claims, the Constitutional Tribunal concluded that Republican agreements 'created, in fact, justified expectations of the Polish citizens for enacting in internal law settlements covering property loss as a result of the change in borders following the World War II. Therefore, this issue could not have been omitted in the internal law and for many years the Polish legislator has attempted to create special compensation mechanisms to solve the matter. ${ }^{38}$

immunities of a given body, but particularly of the EU as such. (...) It seems that there are no essential obstacles that would impede treating the future agreement on the headquarters of Frontex in Poland, as an international agreement' (p. 63).

47 'It follows that, whilst forming an integral part of the EU legal order when it enters into force, the agreement envisaged may not be relied on directly in its own right. Neither the courts of the European Union nor the courts or tribunals of the Member States may therefore apply that agreement directly in the disputes which are brought before them. There are therefore two co-existing legal systems, interference between which has been deliberately limited.' The opinion of the Advocate General Yves Bot, presented on 29.1.2019 on the Opinion 1/17, para. 63. The existence of this clause was one of the arguments that decided on the compliance of the CETA with the EU law, see: Opinion 1/17, ECLI:EU:C:2019:341, 30.4.2019, paras. 77-78.

48 Judgment of the Constitutional Tribunal of 19.12.2002, K33/02, para. 6. See also: R. Kwiecień, Charakter prawny i znaczenie umów repatriacyjnych z 9 i 22 września 1944 roku (Legal Character and Significance of Repatriation Agreements of 9 and 22.9.1944), 
An example of non-ratified and unpublished treaties, with the simultaneous problems of their interpretation, are the indemnification agreements. The Polish government, accepting the responsibility resulting from international obligations following the World War II, obliged itself to pay compensation for the property seized from persons who possessed citizenship of a foreign state or legal persons who belonged to them. In consequence, in 1948-1971, Poland concluded 12 indemnification agreements with 13 states (France, Denmark, Switzerland, Sweden, Great Britain, Norway, the United States, Belgium and Luxembourg, Greece, the Netherlands, Austria and Canada), whereby it transferred funds to satisfy the claims of the citizens of these states or their legal persons whose property was subject to nationalisation or other types of seizure. ${ }^{49}$ The indemnification agreements assumed that the Polish state would transfer a specific, global amount of money, to satisfy the claims of foreign states, while they would take responsibility for payment of compensations to their citizens and legal persons. ${ }^{50}$ In reference to these agreements, an act of 9.4.1968 on making entries in land and mortgage registers to the benefit of the State Treasury, on the basis of the international agreements regarding the settlement of financial claims was passed. ${ }^{51}$ Its premises were however problematic, as it assumed that indemnification settlements constituted the legal grounds for changing the ownership. ${ }^{52}$ As a result,

'Przegląd Sejmowy' 2005, no. 13 (4), p. 9-22. In this context, A. Wyrozumska indicates the indirect effect of the non-ratified agreements 'obligating the state bodies to act for the purpose of their execution', A. Wyrozumska, Prawo międzynarodowe oraz prawo Unii Europejskiej a konstytucyjny system źródeł prawa. (The International Law and the Law of the European Union and the Constitutional System of Legal Sources), [in:] K. Wójtowicz (ed.), 'Otwarcie Konstytucji RP na prawo międzynarodowe i procesy integracyjne' (Opening the Constitution of the Republic of Poland to the International Law and Integration Processes), Wydawnictwo Sejmowe, Warsaw 2006, p. 69; cf. the view of L. Garlicki: nonratified agreements 'cannot influence the legal situation of third parties, in particular, the situation of citizens and similar entities. Here, the same principles apply, as those resulting from Article 93 of the Constitution', L. Garlicki, Polskie prawo konstytucyjne (The Polish Constitutional Law), Wolters Kluwer, Warsaw 2014, p. 143.

49 Judgement of the Constitutional Tribunal of 24.10.2000, SK 31/99, para. III.2.

50 The response of the Secretary of State at the Ministry of Finance - acting on behalf of the Minister - to the parliamentary question no. 22171 regarding indemnification settlements signed by Poland in 1948-1971 of 3.12.2013.

51 Polish OJ 1968, item 65.

52 J. Barcz, Opinia prawna $w$ sprawie relacji między układami indemnizacyjnymi zawartymi przez Polskę z dwunastoma państwami zachodnimi a dekretem z dnia 26 
the judicature of Polish courts, to a certain degree, reinterpreted the essence of indemnification agreements in a way that was unfavourable for the State Treasury's interests. ${ }^{53}$

There are cases where the Republic of Poland bound itself with international agreements, which, for various reasons, have not been implemented yet, although they may be applied to individuals. These are mostly agreements regarding very specific areas and in consequence relating to relatively narrow group of individuals. One should also indicate that this state of affairs relate to treaties signed by Poland before the entry into force of the Constitution of 1997. This group of agreements primarily includes the 1959 Antarctic Treaty ${ }^{54}$ along with the 1991 Protocol on Environmental Protection, ${ }^{55}$ which require legislative implementation in the domestic legal system. According to those treaties there is a need for establishing internal procedure of acquiring prior permit ${ }^{56}$ and setting environmental requirements ${ }^{57}$ in the case of planning an expedition to Antarctica, establishing the procedure of acquiring a permit to conduct operations on the Antarctic Specially Protected Area, ${ }^{58}$ or setting environmental requirements for the captain of a ship, who intends to enter the Antarctic area. ${ }^{59}$ The issue of establishing appropriate domestic regulation in this

października 1945 r. o własności i użytkowaniu gruntów na obszarze m.st. Warszawy, ze szczególnym uwzględnieniem aspektów prawnomiędzynarodowych (Legal opinion regarding the relations between indemnification settlements concluded by Poland with twelve Western states and the Decree of 26.10 .1945 on property and usufruct of land in the area of the capital city of Warsaw, with special consideration of the international legal aspects), available at: https://www.um.warszawa.pl/sites/all/files/download_file. php?file=/sites/default/files/attach/aktualnosci/opinia_prawna_-_prof_jan_barcz.pdf, p. 3; M. Pilich, Międzynarodowe umowy indemnizacyjne w praktyce sq̨dów (The International Indemnification Agreements in Judicial Practice), [in:] M. Pilich (ed.), 'Reprywatyzacja w orzecznictwie sądów' (Reprivatisation in Jurisprudence), Warsaw 2016, p. 133; see also: M. Muszyński, Nacjonalizacja mienia cudzoziemców w Polsce a problem rekompensaty za mienie pozostawione,(Nationalisation of Property of Foreigners in Poland and the Problem of Compensation for the Abandoned Property), 'Przegląd Sejmowy' 2006, no. 1, p. 65.

53 See e.g.: IV SA/Wa 1524/07 of 26.11.2008; IV SA/Wa 2142/10 of 28.1.2011; IV SA/Wa 2079/10 of 28.12.2010; IV SA/Wa 230/10 of 21.4.2010; IV SA/Wa 1943/07 of 7.12.2007; IV SA/Wa 1501/07 of 2.10.2007.

54 Polish OJ 1961, item 237, with subsequent changes.

55 Polish OJ, item 52, with subsequent changes.

56 Article VII(5), letter a of the Antarctic Treaty.

57 Article 2 (Apendix no. I) of 1991 Protocol on Environmental Protection.

58 Article 7(1) of the Apendix no. V to the Protocol.

59 Article 9 of the Apendix no. IV to the Protocol. 
regards seems particularly important, considering the increasing tourist traffic in the region. ${ }^{60}$

A different example, of a similar type, is the lack of domestic regulation implementing into the Polish legal system the basic obligations resulting from the treaties regarding the Outer Space, especially the Treaty on Principles Governing the Activities of States in the Exploration and Use of Outer Space, including the Moon and Other Celestial Bodies of 27.1.1967, ${ }^{61}$ the Convention on International Liability for Damage Caused by Space Objects of 29.3.1972, ${ }^{62}$ as well as the Convention on Registration of Objects Launched into Outer Space of $12.11 .1974 .{ }^{63}$ In this respect, the issue of non-implementation was noticed by state organs and in August 2014 the Minister of Economy prepared draft objectives for the Act on the Space Law. ${ }^{64}$ The Act would regulate the principles of conducting space operations, in particular launching a space object, its exploitation and, possibly, its return to Earth. Space operations would be conducted only after receiving permission, and the Act would constitute the legal grounds for the establishment and functioning of the National Registry of Objects

60 Cf. 'the issue of the intensification of non-government activities in the Antarctic area, with its most vivid example being Antarctic tourism (...). On the one hand, this phenomenon raises new challenges regarding the management of this area (e.g. regarding environmental protection and security). On the other hand, it poses a legal-organisational challenge for every state related to the establishment of an appropriate system that would allow the acquisition of knowledge on tourist activities undertaken by its citizens, or on its ships or territory, and its appropriate regulation, among others, in the light of the binding requirements of the Madrid Protocol and apendices thereof', K. Marciniak, System Układu Antarktycznego: uwagi z perspektywy prawa międzynarodowego. (The Antarctic Treaty System: notes from the international law perspective), [in:] 'Układ Antarktyczny Wybór dokumentów z wprowadzeniem' (The Antarctic Treaty. A Selection of Documents with Introduction), Ministerstwo Spraw Zagranicznych, Warsaw 2017, p. 59-60.

61 Polish OJ 1968, item 82 appendix no. 2.

62 Polish OJ 1973, item 154 appendix.

63 Polish OJ 1979, item 22 appendix .

64 The draft objectives of the bill is available at: https://radalegislacyjna.gov.pl/ sites/default/files/dokumenty/projekt_zalozen_prawo_kosmiczne.pdf; As regards the origins of this legislative process in Poland, see: A. Misztal, Ł. Kułaga Znaczenie prawa kosmicznego w polskiej polityce zagranicznej (Significance of the Space Law in the Polish Foreign Policy), [in:] K. Myszona-Kostrzewa (ed.), 'Kosmos w prawie i polityce, prawo i polityka w kosmosie' (Space in Law and Politics, Law and Politics in Space), Scholar, Warsaw 2017, p. 19-20. 
Launched into Outer Space. ${ }^{65}$ However, until now, the legislative works in the Republic of Poland have not gone beyond the process of consultation within the Council of Ministers, despite the fact that adoption of the ACT was included in the National Space Programme for 2019-2021. ${ }^{6}$

\subsection{Implementation - time factor}

The presented examples of the treaties that have not been implemented into the Polish legal system yet lead to the necessity of reflection on the time factor in this respect. Anthony Aust deduced from Articles 26 and 27 of the VCLT the following:

if a new law, or modification to an existing law, is needed (the law may already be in place) in order to carry out the obligations imposed by a treaty, a negotiating State should ensure that this is done at least by the time the treaty enters into force for that party. If this is not done, not only will the State risk being in breach of its treaty obligations, but it will be liable in international law to another party if this results in that party or its nationals suffering harm. Although it may be tempting, a State cannot plead that it is waiting for its parliament to legislate. Even if the treaty does not enter into force for the State at the time it consents to be bound, the date of entry into force may come earlier than expected. It is therefore desirable that any necessary legislation is in place before the State gives its consent, though the actual coming into force of the legislation can certainly be postponed until the entry into force of the treaty for that State. ${ }^{67}$

The premise, that the Republic of Poland should implement an international agreement, particularly one that grants rights to individuals before its ratification, does not seem to raise much controversy prima facie, especially taking into account already mentioned interpretation of Article 9 of the Constitution. Such action seems to be confirmed by the treaty practice. For example, the Minister of Justice for few years refused the

65 See https://legislacja.rcl.gov.pl/docs//2/12300856/12449058/12449059/ dokument 300891.pdf

66 The document is available at: https://polsa.gov.pl/images/KPK/Krajowy-ProgramKosmiczny-na-lata-2019-2021_7.12.2018.pdf, p. 108.

67 A. Aust, Pacta Sunt Servanda, 'Max Planck Encyclopedia of Public International Law' (online edition), para. 13. 
ratification of the Council of Europe ( $\mathrm{CoE}$ ) Convention on Cybercrime of 2001, justifying his decision by the lack of appropriate adjustment of the Polish law to the Convention. ${ }^{68}$ A similar position was taken by the Minister of Foreign Affairs in reference to the Protocol no. 12 to the Convention for the Protection of Human Rights and Fundamental Freedoms of 4.11.2000, ${ }^{69}$ Minister of Justice with respect to the International Convention for the Protection of All Persons from Forced Disappearance of 20.12.2006, ${ }^{70}$ as well as the Minister of Internal Affairs regarding the Convention on the

68 'Due to the difference in views regarding the full compliance of the domestic provisions with the requirements resulting from the Convention, the Ministry of Justice commissioned an expertise, which shows that it is imperative to introduce certain legislative amendments to the Criminal Code and the Code of Criminal Procedure. The amendment regarding the age of the minor, who is included in the recording or production of pornographic contents, is considered to be of particular significance. The Convention defines the age as no less than 16 years, while the Polish law provides for the liability of a person who records or produces pornographic content with a participation of minors below 15 years of age (Article 202(4) and (4a) of the Criminal Code). This and other discrepancies currently impede the ratification of the Convention by Poland (...). Regardless thereof, the Ministry of Justice has drawn up an Act on the amendment of the Act on the Criminal Code and Certain Other Acts in order to ensure full compliance of the domestic law, among others, with the Convention on Cybercrime, allowing to formally bind with the instrument and its accompanying protocol.' See: The response of the State Secretary at the Ministry of Justice - on behalf of the Minister - to the parliamentary question no. 19353, regarding the ratification of the Convention on Cybercrime with the Additional Protocol on Combating Racism of 6.8.2013.

69 The response of the Undersecretary of State at the Ministry of Foreign Affairs - on behalf of the Minister, to the parliamentary question no. 26893 regarding the current state of the ratification of international obligations of the Republic of Poland, related to the Council of Europe Convention for the Protection of Human Rights of 8.7.2016, para. 3.

70 The response of the Undersecretary of State at the Ministry of Foreign Affairs - on behalf of the Minister - to the parliamentary question no. 26509 regarding the current state of the ratification of international obligations of the Republic of Poland, related to the United Nations Convention for the Protection of Human Rights of 1.7.2014, para. 13 'The ratification requires adjustment of the domestic law provisions regarding the family law to the provisions of the Convention. The Polish law does not provide for the annulment of adoption (with ex tunc effect), but only dissolution thereof (with an ex nunc effect and with the exclusion of full undissolvable adoption). Whereas, the Convention requires the domestic law to provide for a possibility of annulling adoption initiated by forced disappearance. A project was drawn up at the Ministry of Justice regarding the assumptions of the Act on the Amendment of the Act on the Civil Code, the Act on the Family and Guardianship Code, the Act on the Family Support and Foster Care System and Certain Other Acts, which introduces the institution of annulling adoption due to 
Reduction of Statelessness of 30.8.1961 ${ }^{71}$ and the European Convention on Nationality of 1.11.1997. ${ }^{72}$

The Minister of Labour and Social Policy initiated the ratification process of the Convention on the Rights of Persons with Disabilities 'as it was stated, that the Polish law is compliant with provisions thereof. Stating compliance of the Polish law with the Convention was possible, among others, due to the introduction of the following important changes in the recent years ${ }^{73 ،}$. Due to the existence of two provisions the Convention, which were not implemented by the Polish law - the right to perform legal transactions and to contract marriage (respectively, Article 12(4) and Article 23(1)(a) of the Convention), the Council of Ministers decided

causes existing at the moment of adjudging of this relationship with the ex tunc result. The adoption of this solution would open the path to the ratification of the convention.'

71 The response of the Undersecretary of State at the Ministry of Foreign Affairs - on behalf of the Minister - to the parliamentary question no. 26509 regarding the current state of the ratification of international obligations of Poland related to the United Nations Convention for the Protection of Human Rights of 1.7.2014, point 15 'On 15.8.2012 the provisions of the new Act of 2.4.2009 on Polish Citizenship (consolidated text of Polish OJ 2012, item 161, as amended), has gone into effect) including both, systemic changes of the state, as expressed in the Constitution of the Republic of Poland, and the development of the basic legal principles regarding citizenship. The regulations included in the Act on Polish Citizenship allowed to initiate a discussion on Poland's accession to the Convention on the Reduction of Statelessness of 30.8.1961. Currently, at the Ministry of Internal Affairs, a request is being prepared for being bound with the Convention, in compliance with the Act on International Agreements of 14.4.2000.'

72 The response of the Undersecretary of State at the Ministry of Foreign Affairs - on behalf of the Minister - to the parliamentary question no. 26509 regarding the current state of the ratification of international obligations of the Republic of Poland, related to the United Nations Convention for the Protection of Human Rights of 1.7.2014, para. 39. 'The Republic of Poland did not ratify the European Convention on Nationality of 1.11.1997, due to the fact, that the Act on Polish Citizenship of 15.2.1962 (Polish OJ, no. 10 , item 49 , as amended) binding at the time of adopting the convention, was in part non-compliant with provisions thereof. On 15.8.2012, a new Act of 2.4.2009 on Polish Citizenship entered into force (consolidated text of Polish OJ 2012, item 161, as amended), which included both, the systemic changes of the state stipulated in the Constitution of the Republic of Poland, as well as the development of the basic legal principles related to citizenship and in particular, the principles included in the European Convention on Nationality. Currently, the Ministry of Internal Affairs is drawing up a request for the ratification of the European Convention on Nationality.'

73 Information available in 2015 at the website: www.mpips.gov.pl/spoleczne-prawa-czlowieka/organizacja-narodow-zjednoczonych/konwencja-o-prawach-osob-niepelnosprawnych/ratyfikacja-konwencji-o-prawach-osob-niepelnosprawnych-przez-polske/. 
to submit an interpretative statement and a reservation so as not to put the ratification process on hold. ${ }^{74}$

Additionally, it is worth noting the example of the CoE Convention of 16.5.2005 on Action against Trafficking in Human Beings, Article 25 of which states that 'Each Party shall adopt such legislative and other measures providing for the responsibility to take into account final sentences passed by another Party in relation to offences established in accordance with this Convention when determining the penalty.' Poland submitted a statement addressing this Article, indicating that the effective implementation of the obligations thereunder: 'requires establishing efficient international legal and technical mechanisms related to the exchange of information regarding judgments issued by the other $\operatorname{Party}(. ..) .{ }^{75}$ The justification for this solution indicated that 'currently, the Republic of Poland does not possess legal and infrastructural instruments that would allow actual enforcement of Article 25. ${ }^{76}$

What is interesting, within the framework of the Polish government administration, a number of discrepancies appeared with regard to the $\mathrm{CoE}$ Convention for the Protection of Human Rights and Dignity of the Human Being with regard to the Application of Biology and Medicine (hereinafter OVIEDO) and the CoE Convention on Preventing and Combating Violence Against Women and Domestic Violence (hereinafter CAHVIO). Until now, the Republic of Poland has been bound only with the latter. In both cases, the Minister of Justice and the Minister of Foreign Affairs were of the opinion that it is necessary to ensure the implementation of these conventions into the Polish legal system, before initiation of ratification procedure. ${ }^{77}$ The Government Plenipotentiary for Equal Treatment, responsible for conducting the procedure of binding the Republic of Poland with OVIEDO during the consultation process within the Council of Ministers, noting the

74 Sejm Paper 408 of 27.4.2012, p. 146-147.

75 See http://www.traktaty.msz.gov.pl/fd.aspx?f=P0000015928.pdf.

76 Sejm Paper 374 of 28.3.2008, p. 4 of the justification of the draft Act.

77 A juxtaposition of the comments regarding CAHVIO ratification process was available in a period 2012-2015 at the website: http://bip.kprm.gov.pl/kpr/bipkancelarii-prezesa/projekty-aktow-prawnych/2348,Wniosek-o-ratyfikacje-Konwencjio-zapobieganiu-i-zwalczaniu-przemocy-wobec-kobie.html, and the comparison of the notes regarding OVIEDO was available in 2012-2015 at the website: http://bip.kprm.gov. pl/kpr/bip-kancelarii-prezesa/projekty-aktow-prawnych/2053,Wniosek-o-ratyfikacjeKonwencji-o-ochronie-praw-czlowieka-i-godnosci-istoty-ludz.html. Currently in the author's archives. 
non-implementation of a several Convention's provisions, presented the view the ratification itself will provide 'additional incentive for undertaking necessary legislative action'. A different view on this matter was presented by the Minister of Foreign Affairs and the Minister of Justice. The former indicated that 'Binding the Republic of Poland with the Convention, without prior legislative amendments, shall introduce into the Polish legal system a number of prohibitive norms that shall be of lex imperfecta nature, which, in a situation of issues of such significance, as the biomedical matters, would seem particularly inadequate' and that 'the Convention taking effect in Poland, without appropriate legislative amendments would automatically lead to the state of violation of this binding international agreement (...). As a result, such an action shall constitute a violation of Article 9 of the Constitution of the Republic of Poland. ${ }^{78}$ The Bureau of Research of the Chancellery of the Sejm took a similar approach to the issue indicating that 'Adjusting provisions of the Polish law to the provisions of the Convention should take place before passing the act that would permit ratification thereof. ${ }^{79}$

Article 9 of the Constitution of the Republic of Poland is of crucial importance for the evaluation of the possibility of ratifying the international agreement in the context of the process of its implementation to the Polish legal system. The principle of complying with the international law included therein requires giving effect to the international agreement concluded by the Republic of Poland within the domestic legal order. In a situation when the agreement regulates the rights and freedoms of individuals and enters the spheres reserved for acts, the principle imposes the obligation of adjusting both, the law and the legal practice to the requirements

78 The letter of the Minister of Foreign Affairs of 2.8.2013, available at the website: http://bip.kprm.gov.pl/kpr/bip-kancelarii-prezesa/projekty-aktowprawnych/2053,Wniosek-o-ratyfikacje-Konwencji-o-ochronie-praw-czlowieka-igodnosci-istoty-ludz.html. Currently in the author's archives; for a different opinion see E. Zielińska, Konwencja Bioetyczna. Problemy zwiqzane z ratyfikacja [Bioethics Convention. Problems concerning ratification], [in:] H. Machińska (ed.) '60 lat Rady Europy. Tworzenie i stosowanie standardów prawnych' [60 years of the Council of Europe. Creation and application of legal standards], Oficyna Prawa Polskiego, Warszawa 2009, p. 318.

79 J. Lipski, Opinia prawna na temat zgodności z Konstytucją RP Konwencji Rady Europy o ochronie praw człowieka i godności istoty ludzkiej w odniesieniu do zastosowań biologii i medycyny (The legal opinion regarding the compliance of the Council of Europe Convention for the Protection of Human Rights and Dignity of the Human Being with regard to the Application of Biology and Medicine, with the Constitution of the Republic of Poland), 'Zeszyty Prawnicze BAS’ 2014, no. 2(42), p. 155. 
thereunder. As a result Article 9 of the Constitution should understood as requiring ensuring the compliance of the Polish legal system with the treaty, which is to be ratified not later than on the day of its entry into force with relation to Poland.$^{80}$ Only exceptionally, a lack of such a issuing domestic Act could be justifiable. This would cover the situation if the provisions of a relevant treaty could be applied directly i.e. they have a precise, unconditional and complete character, alternatively concurrently to the ratification procedure, formal legislative works, aiming at the removal of the non-compliance of the Polish legal system, would proceed.

\subsection{Costs of the implementation}

The implementation of a treaty into the domestic legal system generates costs. These are the costs of executive activities, costs associated with the reorganisation of the state organ, the establishment or transformation of the infrastructure, activities in the scope of law application, including payment of compensations in case of breaching the standards defined by the agreement.

The costs of the implementation of treaties has not recently constituted an object of controversy throughout the ratification procedure in Poland. However, there are exceptions. For example, as a result of the dispute between the Minister of Finance and the Minister of Labour and Social Policy regarding the implementation costs of the Convention on the Rights of Persons with Disabilities of 2007, the process of ratification was prolonged for at least 9 months. ${ }^{81}$ Additionally, on occasion, the costs of being party to a treaty is ambiguous or difficult to estimate. For example, while requesting for Poland's accession to the European Space Agency, the Council of Ministers indicated that the obligatory subscription would amount to 19 million Euro, while the optional one, at least in the initial

80 'Traditionally, Australia has been cautious in accepting treaty obligations before enacting the necessary legislation or satisfying itself that existing legislation, federal and state, is adequate', M. Duffy, Practical Problems Of Giving Effect To Treaty Obligations - The Cost Of Consent, 'Australian Yearbook of International Law' 1988/89, vol. 18, p. 19.

81 M. Szreniawska, Znaczenie ratyfikacji Konwencji o Prawach Osób Niepełnosprawnych (The Significance of the Ratification of the Convention on the Rights of Persons with Disabilities), 'Niepełnosprawność - zagadnienia, problemy, rozwiązania' 2012, no. III, p. 10. 
period - to 9.5 million Euro. ${ }^{82}$ Nevertheless, already in 2017, the obligatory subscription reached 21.8 million Euro and the optional subscription - 12.7 million Euro. ${ }^{83}$

\section{Certain remarks on the consequences of the non-implementation}

Prima facie the lack of the implementation of an international agreement into the domestic legal system, in case the agreement cannot be applied directly, causes a situation in which the treaty, if subjected to ratification, is an element of the domestic legal system, however, individuals cannot derive rights therefrom. Nevertheless, it does not mean that the treaty is entirely non-effective in the Polish law. The constitutionally determined openness of the Polish legal system to the international obligations should be also taken into account in this respect.

The principle of compliance with the international law, as defined in Article 9 of the Constitution of the Republic of Poland, imposes on the state institutions the requirement of issuing an interpretation of the domestic law in accordance with the international agreements binding Poland..$^{84}$ As noted by the Supreme Court in the judgement of 29.11.2005, the court is obliged to provide the interpretation of the Polish law in a way that ensures its fullest compliance with the contents of the non-ratified international agreement that binds Poland. ${ }^{85}$

82 Sejm Paper no. 803 of 15.10.2012, p. 22-23.

83 The response of the Minister of Development and Finance to the parliamentary question no. 14032 of August 2017.

${ }^{84}$ As in the Judgment of the Supreme Administrative Court of 26.8.1999 regarding the Geneva Convention relating to the Status of Refugees, V SA 708/99; A. Wasilkowski, Przestrzeganie prawa międzynarodowego (Compliance with the International Law), [in:] K. Wójtowicz (ed.), 'Otwarcie Konstytucji RP na prawo międzynarodowe i procesy integracyjne' (Opening the Constitution of the Republic of Poland to the International Law and Integration Processes), Wydawnictwo Sejmowe, Warsaw 2006, p. 12.

${ }^{85}$ Judgment of the Supreme Court of 29.11.2005, II PK 100/05, OSNP 2006/1920/299; see also D. Sloss, Domestic Application of Treaties, [in:] D. B. Hollis (ed.), 'The Oxford Guide to Treaties', Oxford 2012, p. 394: "Ultimately, the impact of judicial decision-making depends heavily on whether domestic courts pursue a nationalist or transnationalist course. In States where courts tend to adopt a transnationalist approach, domestic courts can play a key role in promoting treaty compliance. India, the 
In the judgement of the Supreme Administrative Court of 24.6.2014, it was even stated that taking into account aforementioned considerations the agreement on international transportation of perishable foodstuffs and the special means of transport dedicated to this transportation should be applied directly to the individual in the with respect to the version of the agreement binding on the date of issuing the administrative decision, even if this new version was not published in the Journal of Laws. The Supreme Administrative Court justified such an approach with and argument that a citizen cannot bear negative consequences of the omission of executing a constitutional and statutory publication duty. ${ }^{86}$

A similar view is expressed in the doctrine indicating that 'the individual is eligible to refer to the beneficial consequences of the unpublished international agreement or amendments thereto. ${ }^{87}$ Simultaneously, one should remember that the interpretation in favour of the international law cannot lead to 'results contrary to the explicit wording of the constitutional norms, which are impossible to be adjusted with the minimum of guarantee functions fulfilled by the Constitution. ${ }^{88}$

The case of already mentioned agreement on international transportation of perishable foodstuffs and on the special means of transport dedicated to this transportation of 1970 , due it's peculiarities, is particularly worth mentioning. Poland adopted an agreement 1983 and also subsequent amendments, however, they latter were not implemented into the domestic legal system. As a solution of this discrepancy between international treaty obligations and difficulty in enforcing them on a domestic level, in 2014 the Council of Ministers decided to initiate ratification procedure of the amended agreement (already binding Poland). This step was considered as

Netherlands, and Poland are leading examples of States where domestic courts actively promote compliance with vertical treaty obligations'.

86 Issued by the cassation of the director of the Customs Chamber against the Voivodeship Administrative Court of 20.12.2012 (file no. II GSK 646/13; WSA).

87 C. Mik, Opinia prawna w sprawie zamiaru ratyfikacji bez uprzedniej zgody wyrażonej $w$ ustawie umowy o międzynarodowych przewozach szybko psujacych się artykułów żywnościowych i o specjalnych środkach transportu przeznaczonych do tych przewozów, sporzqdzonej w Genewie 1 września 1970 r. [Legal opinion regarding the intention, without prior consent given in the Act, to ratify the agreement on international transportation of perishable food stuffs and on special means of transport dedicated to this transportation, drawn up in Geneva on 1.9.1970], 'Zeszyty Prawnicze BAS' 2014, no. 4, p. 91; similarly, A. Wyrozumska, Umowy międzynarodowe..., op. cit., p. 565.

${ }_{88}$ OTK ZU 5/A/2005, item 49. 
to 'allow a validation of the legal status and granting the provisions of the agreement of 1970 the character of a universally applicable law, as well as binding with the already accepted amendments that shall have the same legal status as the primary agreement. ${ }^{89}$ The solution, however precedent, enabled the publication of the contemporary version of the agreement text in the Journal of Laws. ${ }^{90}$

\section{Conclusion}

Ensuring the efficiency of international agreements in the Polish legal system is a complex process that raises controversies both, at the level of executive and judicature. The article listed variety of essential issues in this regards such as the necessity of the implementation of the treaty into the domestic law even before it enter force with respect to Poland (e.g. disputes regarding the OVIEDO Convention), the Republic of Poland's lack of implementation of certain treaties related to use of commons(the Antarctic Settlement, Space Treaties), the implementation into the domestic law of international obligations that are not considered as sources of the international law (referral to international requirements in the aviation law or the agreement regarding the avoidance of double taxation with Taiwan) and finally, the re-ratification of the treaty for ensuring its full efficiency in the domestic legal system.

In this respect it is important that the provisions of the Polish Constitution (Article 9) create presumption of a friendly openness of the Polish legal system towards international obligation, particularly those of a treaty nature. ${ }^{91}$ In this sense, the international legal principle of pacta sunt servanda finds a natural prolongation and reinforcement in the constitutional principles of Poland. The latter allow the domestic courts to assume a proactive position, particularly in reference to the protection of the rights of individuals in the context of non-ratified agreements, or the

89 The Undersecretary of State at the Ministry of Foreign Affairs, Artur Nowak-Far, see: the Full Record of the Meeting of the Committee on Foreign Affairs (no. 147) of 24.9.2014, p. 5.

90 Polish OJ 2015, item 667.

91 W. Czapliński, Relationship between international law and Polish municipal law in the light of the 1997 Constitution and of the jurisprudence, 'Revue Belge de Droit International' 1998, no. 1, p. 266. 
interpretation of the domestic law in compliance with the international law. $^{92}$

\section{Bibliography}

1. Aust A., Pacta Sunt Servanda, 'Max Planck Encyclopedia of Public International Law'

2. Barcz J., Opinia prawna w sprawie relacji między układami indemnizacyjnymi zawartymi przez Polskę z dwunastoma państwami zachodnimi a dekretem z dnia 26 października 1945 r. o własności i użytkowaniu gruntów na obszarze m.st. Warszawy, ze szczególnym uwzględnieniem aspektów prawnomiędzynarodowych

3. Buergenthal T., Self-executing and non-self-executing treaties in national and international law, 'RCADI' 1992

4. Czapliński W., Relationship between international law and Polish municipal law in the light of the 1997 Constitution and of the jurisprudence, 'Revue Belge de Droit International' 1998, no. 1

5. Czepelak M., Umowa międzynarodowa jako źródło prawa prywatnego międzynarodowego, Oficyna Wolters Kluwer, Warsaw 2008

6. Dorr O., Schmalenbach K. (eds.), 'Vienna Convention on the Law of Treaties', Springer-Verlag Berlin Heidelberg 2012

7. Duffy M., Practical Problems Of Giving Effect To Treaty Obligations - The Cost Of Consent, 'Australian Yearbook of International Law' 1988/89

8. Dupuy P.-M., International Law and Domestic (Municipal) Law, 'Max Planck Encyclopedia of Public International Law'

9. Edgar A., Thwaites R., Implementing Treaties in Domestic Law: Translation, Enforcement and Administrative Law, 'Melbourne Journal of International Law' 2018, vol. 19, no. 1

10. Gałka K., Zasada przestrzegania prawa międzynarodowego jako zasada konstytucyjna (art. 9 Konstytucji RP), [in:] C. Mik, Ł. Kułaga (eds.), 'Polskie prawo stosunków międzynarodowych', Torun 2018

11. Garlicki L., Polskie prawo konstytucyjne, Warsaw 2014

12. Hofmański P., Recenzja: W. Czapliński, A. Wyrozumska, Sędzia krajowy wobec prawa międzynarodowego, Warszawa 2001, 'Państwo i Prawo' 2002, no. 5

92 K. Gałka, Zasada przestrzegania prawa międzynarodowego jako zasada konstytucyjna (art. 9 Konstytucji RP) (The Principle of Compliance with the International Law as the Constitutional Principle (article 9 of the Constitution of the Republic of Poland)), [in:] C. Mik, Ł. Kułaga (ed.), 'Polskie prawo stosunków międzynarodowych' (Polish Law of International Relations), TNOiK, Toruń 2018, p. 108-109. 
13. Kwiecień R., Miejsce umów międzynarodowych w polskim porządku prawnym państwa polskiego, Warsaw 2000

14. Kwiecień R., Charakter prawny i znaczenie umów repatriacyjnych z 9 i 22 września 1944 roku, 'Przegląd Sejmowy' 2005, no. 13 (4)

15. Lipski J., Opinia prawna na temat zgodności z Konstytucja RP Konwencji Rady Europy o ochronie praw człowieka i godności istoty ludzkiej w odniesieniu do zastosowań biologii i medycyny, 'Zeszyty Prawnicze BAS' 2014, no. 2(42)

16. Marciniak K., System Układu Antarktycznego: uwagi z perspektywy prawa międzynarodowego, [in:] 'Układ Antarktyczny Wybór dokumentów z wprowadzeniem', Warsaw 2017

17. Masternak-Kubiak M., Przestrzeganie prawa międzynarodowego w świetle Konstytucji Rzeczypospolitej Polskiej, Zakamycze, Kraków 2003

18. Mik C., Opinia prawna w sprawie zamiaru ratyfikacji bez uprzedniej zgody wyrażonej $w$ ustawie umowy o międzynarodowych przewozach szybko psujących się artykułów żywnościowych i o specjalnych środkach transportu przeznaczonych do tych przewozów, sporzadzonej w Genewie 1 września 1970 r., 'Zeszyty Prawnicze' BAS 2014, no. 4(44)

19. Mik C., Fenomenologia regionalne integracji państw. Studium prawa międzynarodowego, vol. II, Regionalne organizacje integracyjne z perspektywy analitycznej prawa międzynarodowego, Warsaw 2019

20. Mik C., Kułaga Ł. (eds.), Polskie prawo stosunków międzynarodowych, Toruń 2018

21. Misztal A., Kułaga Ł., Znaczenie prawa kosmicznego w polskiej polityce zagranicznej, [in:] K. Myszona-Kostrzewa (eds.), 'Kosmos w prawie i polityce, prawo i polityka w kosmosie', Warsaw 2017

22. Muszyński M., Nacjonalizacja mienia cudzoziemców w Polsce a problem rekompensaty za mienie pozostawione, 'Przegląd Sejmowy' 2006, no. 1

23. Nahlik S. E., Kodeks prawa traktatów, Warsaw 1976

24. Pilich M. Międzynarodowe umowy indemnizacyjne w praktyce sq̨dów, [in:] M. Pilich (ed.), 'Reprywatyzacja w orzecznictwie sądów', Warsaw 2016

25. Rosenne S., Developments in the Law of Treaties 1945-1986, Cambridge 1989

26. Skubiszewski K., Stosowanie i przestrzeganie prawa międzynarodowego w państwie, 'Państwo i Prawo' 1984, no. 9

27. Sloss D., The Role of Domestic Courts in Treaty Enforcement: A Comparative Study, Cambridge 2009

28. Sloss D., Domestic Application of Treaties, in: D. B. Hollis (eds), 'The Oxford Guide to Treaties', Oxford 2012

29. Sozański J., Implementacja umów międzynarodowych do systemów prawakrajowego, ze szczególnym uwzględnieniem Włoch (w tym status regionów), 'Roczniki Nauk Prawnych' 2007, vol. XVII, no. 2

30. Szreniawska M., Znaczenie ratyfikacji Konwencji o Prawach Osób Niepełnosprawnych, 'Niepełnosprawność - zagadnienia, problemy, rozwiązania' 2012, no. III 
31. Ulfstein G., Marauhn T., Zimmermann A. (eds.), Making Treaties WorkHuman Rights, Environment and Arms Control, Cambridge 2007

32. Villiger M., Commentary to Vienna Convention on the Law of the Treaties, Brill 2009

33. Wasilkowski A., Przestrzeganie prawa międzynarodowego, [in:] K. Wójtowicz (ed.), 'Otwarcie Konstytucji RP na prawo międzynarodowe i procesy integracyjne', Warsaw 2006

34. Wyrozumska A., Umowy międzynarodowe. Teoria i praktyka, Warsaw 2006

35. Wyrozumska A., Prawo międzynarodowe oraz prawo Unii Europejskiej a konstytucyjny system źródeł prawa, [in:] K. Wójtowicz (ed.), 'Otwarcie Konstytucji RP na prawo międzynarodowe i procesy integracyjne', Wydawnictwo Sejmowe, Warsaw 2006

36. Zielińska E., Konwencja Bioetyczna. Problemy zwiq̨zane z ratyfikacja, [in:] H. Machińska (ed.) '60 lat Rady Europy. Tworzenie i stosowanie standardów prawnych', Oficyna Prawa Polskiego, Warszawa 2009

37. Zieliński M., Porozumienie dotyczące siedziby agencji Unii Europejskiej Frontex w Polsce (aspekty konstytucyjne), 'Przegląd Sejmowy' 2016, no. 1 